\title{
Reflexões sobre a Biologia e a EducaÇão no CURRÍ́CUlo de PEDAGOGIA E NAS LICENCIATURAS*
}

\author{
André Barcellos Carlos de Souza** \\ Os professores são maus implantadores \\ das idéias dos outros. \\ MCDonaLD
}

A razão não pode tornar-se, ela mesma, transparente enquanto os homens agem como membros de um organismo irracional.

HORKHEIMER

\section{RESUMO}

Na reforma curricular do curso de Pedagogia a disciplina Biologia Educacional foi excluída. Entretanto, essa disciplina é essencial na formação do professor. Atualmente, a representação social de ser humano, e obviamente também dos alunos de Pedagogia, é construída mediante uma visão reificada hegemônica, que podemos conceituar como sendo inatista, empirista e imutável. Essa representação de homem não é apenas um equívoco teórico, uma falha na compreensão da realidade, mas uma falha que tem implicações políticas relevantes. Assim, este artigo insere-se na perspectiva de refletir sobre as relações entre a Biologia e a Educação, no intuito de contribuir para transformar, por meio do esclarecimento, a representação social de homem em conceito, contribuindo para o processo de desreificação da sociedade. E, de passagem, defender a existência da disciplina Biologia e Educação nos currículos de Pedagogia e das licenciaturas.

Palavras-chave: biologia e educação; biologia educacional; representação social.

A reforma curricular do curso de Pedagogia, da Faculdade de Educação da Universidade Federal de Goiás, no periodo de 2000 a 2003, motivou debates amplos e específicos, da teoria sobre currículo à concep-

\footnotetext{
* Artigo recebido em 3/5/2004 e aprovado em 25/6/2004.

** Mestre em Educação Brasileira. Professor Assistente da Faculdade de Educação-UFG.
} 
ção de universidade, passando pelo atendimento de diretrizes legais e regulamentações, bem como contemplou os debates nacionais envolvendo as associações e os fóruns ligados à educação, e culminou em uma proposta curricular que

reafirma a docência como base da identidade do pedagogo e propõese a formar professores que compreendam as complexas relações entre educação e sociedade, pensem e realizem a existência humana, pessoal e coletiva, e o trabalho pedagógico com vistas à transformação da realidade social, à superação dos processos de exploração e dominação, à construção da igualdade, da democracia, da ética e da solidariedade. (FACULDADE DE EDUCAÇÃo, 2003, p. 14)

Os debates contribuíram para esclarecer pontos específicos de disciplinas e também para explicitar diferentes concepções de docência. Porém, este artigo trata exclusivamente do debate sobre uma disciplina que na reforma deixou de ser obrigatória, a Biologia Educacional. E o viés adotado não visa problematizar as relações de poder na construção de um currículo, mas, tão somente, refletir sobre a essencialidade de se discutir a relação entre a Biologia e a Educação na formação do professor.

Atualmente, poucos cursos de Pedagogia no Brasil, menos ainda nas licenciaturas, têm em seus programas conteúdos curriculares que contemplem a relação entre a Biologia e a Educação, mas podemos afirmar que, na maioria dos cursos, a orientação epistemológica que norteia as reflexões dessas relações aproxima-se da maneira como essa problemática era e, ainda em parte, é tratada na Faculdade de Educação.

Um dos programas da disciplina Biologia Educacional de 1993 traz a seguinte epígrafe: "Antes de ser um ser social e psíquico o homem é um ser físico e como tal deve ser considerado." Certamente é uma ótima escolha para um plano de curso que tem os seguintes objetivos:

Como a Biologia Educacional é o estudo dos fatores biológicos que determinam as diferenças e variações individuais da espécie humana e dos meios com que o educador pode atuar sobre estes fatores a fim de atingir, para o indivíduo, o máximo de saúde e de eficiência física, mental e social, propõe-se os seguintes objetivos para o presente curso: 1. analisar os fatores biológicos que interferem diretamente no processo de crescimento e desenvolvimento do escolar e sua relação com a aprendizagem; 2 . analisar os problemas de saúde do escolar e 
suas possíveis soluções e 3. planejar programas que visem à melhoria da saúde do escolar.

Ainda a propósito da história da disciplina, percebemos coerência entre a epígrafe e os objetivos com a ementa da disciplina, assim definida:

Genética, sistema nervoso, sistema endócrino, problemas de saúde do escolar, possibilitando a compreensão dos fatores biológicos que interferem no processo de desenvolvimento e aprendizagem e a análise dos problemas de saúde da população escolar de $1^{\circ}$ e $2^{\circ}$ graus. (UFG, 1984)

$\mathrm{Na}$ forma como foi instituída e trabalhada, podemos e devemos afirmar que disciplina Biologia Educacional perpetua uma contradição, pois reproduz a representação social hegemônica de ser humano, na qual existe uma separação, uma ruptura, uma cisão entre a natureza biológica e a natureza social na constituição do ser humano. Essa perspectiva dicotômica contribui negativamente para a construção de teorias científicas explicativas porque toma a condição biológica como imutável, pois estudam-se fatores biológicos como a genética e o sistema endócrino na intenção de se explicar o comportamento dos indivíduos.

Poderíamos recuar na história do pensamento ocidental até os gregos e apontar as bases e as atualizações das idéias inatistas. Na fábula dos três homens, Sócrates dizia que a humanidade era dividida em três tipos de homens: os homens de bronze trabalhavam, os de prata legislavam e os de ouro governavam. Antropólogos, sociólogos e filósofos apontam, desde a mais remota antiguidade até os dias de hoje, as inúmeras formas de criação e recriação dessas concepções, por vezes com sutilezas que dificultam a sua denúncia e superação, como, por exemplo, a idéia de talento das grandes personalidades. Outras vezes aparecem de maneira mais bárbara e violenta, como em Auschwitz. É importante frisar que a perspectiva inatista não está, como pode parecer, circunscrita a grupos, épocas ou sociedades, porque, de fato, ela permeia toda a hitória do conhecimento sobre o homem. Embora sua forma seja concretizada na Biologia moderna, essa ciência deve ser entendida apenas como uma das suas expressões, porquanto recria ratificando as teses inatistas.

A histórica proposta da disciplina Biologia Educacional concretiza uma racionalidade instrumentalizada em que os conceitos da Biologia são transpostos indevidamente para uma natureza humana que, transcen- 
dendo o biologicamente dado, consiste em sua transformação. Assim instrumentalizados, os conceitos das ciências naturais não contribuem para superar pela maneira científica os preconceitos produzidos em uma compreensão irrefletida e vulgarizada das condições humanas na sociedade. Antes, pelo contrário, contribuem para perpetuação de uma representação naturalizada de homem, reproduzindo, por exemplo, idéias como: a divisão entre as classes sociais, as relações entre dominantes e dominados e os comportamentos sexuais como expressões biológicas, pois, como diz a epígrafe do referido histórico programa, o ser humano é, antes de tudo, "um ser físico, e como tal ele deve ser considerado".

Pode-se argumentar que a Biologia Educacional, estruturada dessa maneira, trataria de ajudar a construir o repertório dos alunos quanto à natureza biológica do indivíduo, enquanto as outras disciplinas constroem o repertório quanto à natureza social, separando o estudo de suas naturezas em tempos e espaços distintos, e que caberia ao aluno a síntese conceitual. Esse argumento lembra a discussão entre as disciplinas teóricas e as disciplinas da prática, na qual também cabe ao aluno a síntese solitária da práxis, sem a mediação do professor.

À proporção que a teoria científica em geral e a Biologia em particular tomam a representação de ser humano pelo seu conceito, assumem a aparência natural do homem pela essência natural humana, concorrendo para a manutenção das condições de produção e reprodução de um determinado tipo de sociedade. Como a atual condição social do homem é representada como (pre)determinada geneticamente, as relações sociais são tomadas como imutáveis. O ser humano é representado como imutável, como a-histórico, não existe o vir-a-ser, ele é. Portanto, a forma de organização da sociedade é representada como a única forma possível de organização, já que é organizada segundo uma natureza humana, dada a priori. A desconsideração da perspectiva de síntese nas reflexões engendra o risco de produzir visões dicotomizadas, fragmentárias da realidade, portanto, falsas, prejudicando a reflexão sobre a realidade, concorrendo para mantê-la em vez de superá-la, principalmente em se tratando de processos de formação.

Uma questão também notável e histórica é a da prevalência das ciências sociais na condução da formação do professor, o que é até justificável. Podemos confirmar isso partindo da primeira linha do segundo item, do já referido projeto político-pedagógico elaborado e aprovado em 2003, intitulado “A docência em educação infantil e anos iniciais do ensino 
fundamental: sentido, eixos epistemológicos e objetivos do currículo". Esse projeto afirma que "a educação é uma prática sociocultural e, portanto, inseparável das humanidades, sobretudo da filosofia, das artes, das letras e das ciências sociais." Entretanto, a desconsideração por completo de se refletir sobre as ciências naturais em sua formação é um erro injustificável, pois, se o conhecimento do ser humano do ponto de vista biológico é fundamental para conceituá-lo sob pena de produzirmos falsas sínteses, a reflexão sobre o conhecimento produzido pelas ciências naturais, especialmente pela ciências biológicas, também é essencial.

A princípio, as duas categorias podem ser tomadas como uma única questão, mas não são. São categorias interdependentes, mas distintas. Uma coisa é o estudo do ser humano na perspectiva biológica, e outra coisa é a reflexão sobre a perspectiva biológica no estudo do homem.

O homem deve ser compreendido como resultado da síntese da filogenia e da história sociocultural, embora não possa nunca ser entendido como produto acabado. A forma de organização dos seres humanos não pode ser explicada pelas leis naturais, pois a organização social humana, ao mesmo tempo que transcende, também constitui a sua natureza biológica. E, como a forma de organização social também é essência humana, o homem deve ser analisado e compreendido dessa maneira, na interação entre a sua natureza biológica e a sua natureza social. Desse modo, é injustificável considerar a idéia de uma natureza humana que reduza o homem ou à dimensão biológica ou à dimensão social (CHAUí, 1995, p. 88).

O foco de iluminação da segunda categoria é o método das ciências naturais, ou melhor, das ciências experimentais. As ciências experimentais que produzem conhecimentos partindo da intervenção humana sobre os fenômenos a fim de descrever, interpretar e compreender fenômenos semelhantes e prever novos, ainda são, sem dúvida, desde a constituição da ciência moderna, importante fonte organizadora e produtora da ordem social, sobretudo porque a representação social idealista da teoria permanece pouco alterada quando tributa-se a possibilidade de conhecermos as leis universais para as coisas e as culturas. Os conjuntos de conceitos empregados na determinação da natureza sem vida são os mesmos para classificar e explicar a natureza viva. E mais: tais elaborações conceituais são admitidas como categorias explicativas pelas mais diversas escolas sociológicas. Os princípios teóricos, segundo Horkheimer (1991), são tradicionalmente determinados pela percepção de que os 
fatos ocorridos, bem como as aplicações das explicações teóricas dos fatos concretos, sejam algo exterior ao teórico, o especialista apenas registra e revela seus registros na forma de orientações a serem seguidas pelos homens comuns, e baseiam suas indicações conceituais na compilação de enormes quantidades de dados, sempre interpretados à luz de sistemas matemáticos. A conjuntura social burguesa, na sua divisão de trabalho, confere uma representação a esse especialista digna de reconhecimento inconteste. É óbvio que esse reconhecimento não se dá $a$ priori, mas é conferido, porque as teorias formuladas representam efetivamente a legitimação e a sustentação do sistema de produção dominante, conformando suas teorias às próprias determinações de classe.

Contudo, o comportamento teórico crítico deve ser a exposição das contradições sociais para estimular a transformação conceitual e ao mesmo tempo ser o próprio agente transformador das mudanças culturais, na medida em que elimina a separação entre indivíduo e sociedade porque

considera ser o contexto condicionado pela cega atuação conjunta das atividades isoladas, isto é, pela divisão dada do trabalho e pelas diferenças de classe, como uma função que advém da ação humana e que poderia estar possivelmente subordinada à decisão planificada e a objetivos racionais. (HORKHEIMER, 1991, p. 44)

Na compreensão do contexto de formação dos pedagogos e licenciados é imprescindível a reflexão em diversas escalas de categorias, e a compreensão aqui proposta pretende dialogar simultaneamente a questão específica da crítica ao modelo tradicional de abordar as determinações biológicas e/ou sociais na espécie humana, como também, e ao mesmo tempo, não perder de vista uma escala maior referente às determinações teórico-metodológicas que constitutem a formação intelectual dos cidadãos profissionalizados pelas faculdades de educação.

A DICOTOMIA ENTRE O BIOLÓGICO E O SOCIAL NAS REPRESENTAÇÕES DE SER humano ENTRE OS ESTUdANTES DO CURSO de PEDAGOgia

Uma pesquisa realizada em 1999 (Carlos de Souza, 2000) indica que não existe diferenças significativas nas representações de ser humano entre os alunos da Pedagogia da UFG. Em geral, têm uma mesma representação de ser humano que, em síntese, compreende o indivíduo 
de maneira inatista, empirista e imutável, corroborando pesquisa realizada por Rego (1994). Tal representação não é, obviamente, apenas decorrente da visão projetada pelo trabalho desenvolvido na disciplina Biologia Educacional, mas, de fato, se o trabalho nessa disciplina continuar a ser organizado da maneira como estabelece a antiga ementa, ou não for possível demandar tempo para abordar essa discussão, certamente será complicado superar essa visão reducionista.

A pesquisa busca compreender as representações sociais de homem dos estudantes na interface do social com o biológico e as suas implicações para a educação. Procura investigar como os alunos compreendem o imbricamento entre a natureza social e a natureza biológica na constituição do ser humano, sendo a concepção de educação norteadora da reflexão.

No espaço da Universidade Federal de Goiás, particularmente na Faculdade de Educação, no curso de Pedagogia, que tem como especificidade formar professores, é possível observar a visão hegemônica em que se dicotomiza o biológico e o social na crença em indivíduos superdotados; na idéia de que, quando a criança nasce, já tem uma dada personalidade; no homossexualismo como um desvio de comportamento geneticamente determinado; na fé da explicação religiosa sobre as diferenças entre uns e outros etc.

Modernamente, no âmbito da Biologia, o aparecimento da clonagem de seres vivos coloca questões novas ao conceito de reprodução biológica. Não se trata de uma técnica desenvolvida na área das ciências biológicas e a ela circunscrita. Como se sabe, a clonagem é a expressão moderna do desenvolvimento técnico, político, estético, ético e científico da humanidade e, como tal, deve ser compreendida. Trata-se de um híbrido do domínio da natureza, da política e do discurso (LATOuR, 1994). Outros avanços científicos produziram reestruturações das representações que as pessoas fazem do mundo. A clonagem de seres vivos, mesmo não possuindo a envergadura de uma revolução científica, também pode ter algum efeito nessas reestruturações, à proporção que se incorpora na vida cotidiana. A possibilidade, mesmo que remota, da clonagem humana instiga e incita reflexões acerca da concepção de educação, indivíduo, sociedade, personalidade, religião, ambiente, mãe, pai, cultura, gene, desenvolvimento, sexualidade, Deus, preconceito, ciência, e uma enorme gama de outras representações. Ocorre, pois, que a possibilidade, mesmo imaginária da clonagem humana, na qual, teoricamente, com base em 
uma célula somática, forma-se um novo ser geneticamente igual ao anterior, pode abalar concepções culturais arraigadas sobre Deus, ciência, tecnologia, ser humano, sociedade, educação, uma vez que concebe um novo ser humano completamente distinto dos padrões vigentes.

A forma como as ciências experimentais são introduzidas no cotidiano da população em geral, bem como outras aplicações científicas modernas, sobretudo no âmbito das ciências biológicas, como a transgenia, a terapia gênica, o mapeamento cromossômico de doenças, sugerem uma fragmentação entre a natureza biológica e a social dos homens. Inúmeros são os exemplos dessa dissociação em nossa sociedade; tanto os exemplos do passado quanto casos modernos reproduzem concepções dicotômicas e sugerem que a problemática tem profundas raízes históricas na sociedade (Lewontin, 1986; PATto, 1993; Bızzo, 1994). A concepção frenológica, ${ }^{1}$ a proposta de uma relação entre o clima e o temperamento na determinação da personalidade, o darwinismo social, o biologismo sociológico, a determinação hereditária, a eugenia, a medicalização dos processos psicológicos e sociais são concepções racistas que têm em comum uma categoria: a dicotomia da relação entre a biologia e a cultura na constituição do ser humano.

Podemos associar essa visão fragmentária a uma outra concepção extremamente importante para a reflexão proposta, que é a percepção da realidade, também fragmentária, que toma o ser humano como imutável, e não como indivíduo inserido em um processo constante de transformação. Essa associação justifica-se, uma vez que, adotando-se um referencial dicotomizante, valendo-se de uma concepção que dissocia o que é indissociável, o ser humano, independente do seu processo de formação e desenvolvimento, é compreendido como um produto acabado. As visões fragmentadas da realidade produzem representações dicotomizadas dos fenômenos; o homem é conhecido pelo que é naquele momento, não se leva em consideração o seu passado, nem o processo de formação por que passa. O indivíduo é retratado como moldado pela sociedade, independentemente de sua carga genética, e, paradoxalmente, pode-se considerar a possibilidade da genialidade ${ }^{2} \mathrm{em}$ um indivíduo, desconsiderando as condições sociais.

Uma notícia jornalística, sobre inteligência, publicada em julho de 1997, expressa bem a visão dicotômica e contraditória da realidade falada há pouco. A reportagem relata que Jonathan Glover, da Universidade de Oxford, isolou o primeiro gene específico responsável pela inteligência 
humana. Segundo o pesquisador, agora se pode avaliar a habilidade cognitiva geral pelo gene IGF2R no cromossomo 6. O professor também declarou, segundo a Agência Estado, que a sua descoberta traria conseqüências sociais e educacionais enormes: "devemos investir mais em pessoas com maior potencial ou devemos compensar aqueles que possivelmente tenham menor potencial genético?" (O POPULAR, 4 nov. 1997).

O pesquisador, os leitores, bem como os repórteres que não contestaram as suas afirmações, reduzem claramente a inteligência a uma condição biológica. A inteligência é considerada um fator social, quando se pensa nos processos educacionais; por outro lado, tem-se um banco de sêmen de gênios para produzir descendentes inteligentes. A fundamentação da idéia da genialidade repousa na visão inatista, e a raiz do pensamento condicionante fundamenta-se na idéia empirista, ambas reducionistas e falsas.

É necessário um estudo quantitativo para afirmar categoricamente que as representações de homem pendem para o inatismo, o que de modo genérico pode-se confirmar. Sem dúvida alguma, o avanço da biotecnologia tem uma grande influência nas representações inatistas. A biologização é marca de nosso tempo. Outras duas notícias jornalísticas publicadas em um mesmo dia, no Jornal do Brasil, atestam a concepção biologizante de ser humano:

A revista New Scientist publicou que o padrão das ondas cerebrais de recém-nascidos pode revelar se eles terão problemas de leitura aos 8 anos.

Cientistas conseguiram transformar ratos machos promíscuos em parceiros fiéis e pais confiáveis, manipulando um hormônio que, nos seres humanos, controla a conduta sexual. (JORNAL DO BRASIL, 19 ago. 1999)

Essas reportagens (também noticiadas em TV), que influenciam a concepção de leitores e espectadores, devem ser analisadas também sob outra perspectiva, pois são produtos da mesma concepção dicotômica referida anteriormente. É necessário percebê-las, sim, como produtoras de opinião, mas também como produtos de opinião pública. A grande maioria da população não contesta essas notícias, pois tem a mesma concepção que os cientistas e os repórteres, isto é, pensam de forma semelhante. 
A questão pertinente que se impõe é: como se representa a relação entre a natureza biológica e a natureza social na constituição do ser humano? Com base nessa questão, é essencial compreender as representações que os estudantes de Pedagogia fazem de seus alunos (ou futuros alunos), como também se se trata das representações que eles fazem de si próprios, de seus pais, dos amigos, de seus professores atuais e antigos. Enfim, se ao representar o homem mediado pela inter-relação entre a cultura e a biologia, os sujeitos representam o processo de constituição do homem independentemente dos atores no processo, portanto, tomam qualquer um como agente do processo, até a si próprios.

As entrevistas com os alunos das três últimas séries do curso de Pedagogia foram realizadas nos meses de setembro e outubro de 1999, e os alunos da primeira série foram inquiridos no primeiro dia de aula e seguiram o mesmo roteiro de perguntas:

1 - Sobre a clonagem humana. Sem entrar no mérito da questão, se é possível, boa ou não. Como você pensa que seria o indivíduo clonado? igual; diferente; igual em que; diferente em que do indivíduo "original"?

2 - O que você pensa a respeito do ditado popular: "Filho de peixe, peixinho é"?

3 - Para você, o processo da educação é um processo social ou é biológico?

4-Qual a origem da singularidade humana? Por que somos diferentes? Qual é a origem dessas diferenças?

5 - O que você pensa a respeito do ditado popular: "Em casa de ferreiro, o espeto é de pau", onde o filho é completamente diferente de seus pais.

Abrindo a entrevista com a pergunta sobre clonagem, a intenção era desorientar o entrevistado, uma vez que dele seriam exigidas, dali por adiante, respostas sem reflexões prévias, bem como pretendia-se deixá-lo confortável na posição à deriva. Essa intenção orientou-se pela notória falta de reflexão da população em geral quando imersa na vida cotidiana (Heller, 1994). Questões, em princípio presentes na cotidianidade, como, por exemplo, a clonagem, por se tratar de objeto que, ao mesmo tempo, insere-se no seu universo consensual, ainda possuem escassa informação. Por outro lado, a opção de trabalhar a 
entrevista com os ditados populares, como a segunda e a quinta pergunta, aparentemente de resposta imediata, tinha o intento de proporcionar uma aparente segurança ao entrevistado, pois, ao tratar de ditados populares, insere-se na entrevista um padrão de linguagem que permite ao entrevistado sentir-se seguro ao responder às perguntas mais complexas.

$\mathrm{O}$ uso dos ditados populares na entrevista tem duas funções. Ao colocar o entrevistado em uma situação cômoda, pois conhece o ditado, cria-se uma zona de segurança necessária para o entrevistado; assim, a tendência é a pessoa não se incomodar com o que fala, sendo bastante espontânea. Portanto, é justamente por conhecer o ditado que se cria entre o entrevistado e o entrevistador uma proximidade fundamental para a entrevista, bem como para sua análise. A outra função - daí a razão da escolha - é que esses ditados têm como característica central o uso cotidiano para explicar as diferenças e as semelhanças entre indivíduos e, assim, ao falar sobre esses ditados, os entrevistados expõem as suas representações de ser humano. Fundamentalmente, buscou-se compreender, mediante entrevistas, os sistemas de interpretação do real dos sujeitos entrevistados, circunscrito ao universo da pesquisa: a relação entre o social e o biológico. Em outras palavras, buscou-se apreender como os sujeitos representam o homem, tendo como referência a sua constituição e o seu desenvolvimento.

Em decorrência das entrevistas, foram eleitas as seguintes categorias de análise: o estranhamento diante das perguntas; o biológico; o social; a religião; a ciência; a imutabilidade. As análises indicam essas categorias como centrais e capazes de orientar algumas inserções sobre a representação de ser humano dos sujeitos entrevistados. As entrevistas foram analisadas mediante as categorias em separado, como também buscaram inter-relações entre os pares das categorias elencadas e entre todas as categorias.

De maneira genérica, podemos depreender das análises que os entrevistados, em relação às categorias, figuram em um continuum que vai desde uma representação muito pouco consistente, fluida, difusa, a uma representação que se aproxima dos conceitos. Esse continuum pode ser melhor compreendido e ilustrado com a categoria de estranhamento como alicerce.

A inexistência de uma base consistente de conhecimento sobre os temas propostos parece uma explicação plausível para o estranhamento sobre o tema das perguntas, revelado nas grandes pausas (silêncio) nas 
respostas, nas freqüentes indecisões, nas trocas de pronomes (eu, nós, eles). A análise sugere que o universo teórico dos alunos de Pedagogia, especificamente no que se relaciona à representação de ser humano, não se apresenta coerente, consistente. Qualquer nova informação, no caso, a clonagem ou a reflexão sobre os ditados populares, ou ainda sobre a origem das diferenças entre os seres humanos, provoca um grande incômodo e uma indecisão, aguçando as contradições do discurso.

Reproduzo integralmente uma entrevista de uma aluna de 33 anos, cursando na época o $4^{\circ}$ ano, solteira, que declara não ter religião e trabalhava como professora em uma escola. Certamente ilustra a síntese produzida a partir das 19 entrevistas analisadas com base nas categorias propostas.

Resposta à questão 1 :

No meu pensamento, se é uma clonagem... Eu acho que é bem parecido, né... (nome do entrevistador), o que será que seria diferente em um indivíduo que é clonado? Se ele é exatamente idêntico ao outro... fisicamente... mas... aí entra a questão... aonde ele vai estar, em que meio ele vai ser inserido... Aí ele pode ser totalmente diferente do outro indivíduo. Eu penso assim... quase que igual aos gêmeos, são idênticos, não são... mas são duas pessoas distintas... Aí fica a minha dúvida... Ele vai ser clonado, será que ele vai ser... pensar igualzinho ao outro? Eu... na minha... no meu pensamento não... porque ele vai receber a realidade a partir dele... e aquele que foi clonado a partir dele... ele já tem o pensamento pronto... Eu fico até curiosa... já vai clonar um indivíduo adulto? E aí... como que você vai fazer todo... processar todos os conhecimentos pra ele... aí a minha dúvida... aí um clone vai ser como? Como que ele vai reagir? Neste meio aqui que ele está inserido? Como que ele vai reagir sabendo que ele é um clonado? Mas pra ele, será que vai ter algum problema? Ele conhece o método... como é concebido os outros seres humanos? É muitas perguntas (nome do entrevistador)... muitas... muitas... muitas... muitas perguntas... [Concordo, mas assim... deixa eu tentar sintetizar... porque eu preciso de uma... deixa eu tentar sintetizar...] agora mostra o caminho que você quer... [não, ao contrário, de jeito nenhum, olha só... a idéia que você me passou é que você... que ele é parecido do ponto de vista físico... não é? mas e do ponto de vista... que não físico... quer dizer social, né...] a construção do conhecimento dele... [a 
construção do conhecimento dele é que vai ser completamente diferente... esse indivíduo...] pode ser... [ah! pode ser...] completamente diferente... [Isto que eu tô querendo entender melhor...] Ok, eu penso... mesmo que eu seja igual a você fisicamente eu vou pensar igual a você? [e a resposta que você tem pra isso...] é não... é não... eu tenho na minha cabeça que não... [então, é... quando você responde, então, quer dizer, aquela pergunta que você fez... pode ser? você responde à pergunta: que não] na minha concepção é que não.

Resposta à questão 2:

Acho que é só um ditado popular, porque... aí a gente pode exemplificar, se eu tenho um pai, que é um alcóolatra, especificamente, eu tenho... é... como se diz... uma predisposição para ser uma alcóolatra, mas o meio social, o meu conhecimento que eu construí... eu posso sair dalí por uma linha totalmente diferente, eu acho que este ditado é só um dito popular, mesmo, ele não se aplica à nossa realidade não. [Então você não concorda...?] Não.

Resposta à questão 3:

Social, não que eu concorde com Durkheim (risos)... porque Durkheim simplifica a educação em um fato social... Eu acho que o processo educacional, ele é social, mas... ele parte da sociedade, mas ele não é simplesmente... um fato social, tem muitas outras coisas envolvidas neste processo. [Quais, por exemplo...] Inúmeros, por exemplo,... o ambiente que ele... é... a concepção que os pais dele têm de educação vai influir nesta pessoa... então não é só isso... A educação ela é muita ampla, eu acho muito difícil... eu estou no quarto ano de pedagogia, e até agora eu não entrei num consenso de como definir a educação... porque você pode ir por vários caminhos... sem deixar pra trás nenhum... aí que é o problema... como juntar todos os caminhos, como conciliar.

Resposta à questão 4:

Oh! meu Deus, a que eu atribuo estas diferenças? Seria o fator genético... pra mim é... porque a minha... a célula que deu origem a mim não é igual a nehuma outra existente, então, dificilmente... Volta naquela questão, impossível nós sermos iguais... podemos ser parecidos, socialmente a gente pode até ficar muito parecidos se a gente receber a mesma educação, talvez a gente vai ter o mesmo tipo de pensamento, ter a mesma ideologia, mas... eu acho que parte daí... do genético, lá da 
célula mesmo... [É isso... quer dizer... é a isso que você atribui, ou seja, somos diferentes porque somos geneticamente diferentes?] Geneticamente diferentes e também socialmente diferentes ... as duas coisas... uma complementa a outra.

Resposta à questão 5:

Eu concordo mais com este, do que com o do filho de peixe, peixinho é... porque o filho pode ser parecidíssimo com o pai, mas nunca vai ser o pai, ele nunca vai ser uma cópia pronta e acabada do pai, o conhecimento dele vai ser construído com a colaboração do conhecimento do pai, mas vai ser o conhecimento dele... Vai ser as suas reações frente a este conhecimento que tá aí... pronto e acabado, então, o pai tem um conhecimento, ele tenta passar isso da mesma forma que ele recebeu pro filho, mas cada pessoa por ser um ser diferente, um ser distinto, cada um recebe de uma forma, então... como é o ditado? em casa de ferreiro, espeto é de pau ... com esse eu concordo... o filho é diferente... não há como ser igual, mesmo clonando eu não acredito nesta igualdade não... [Voltando à questão da clonagem, e aí volto a dizer... independentemente se é possivel, se é bom, se é ruim, tá... em relação a... alma, em relação ao espírito... quê que você pensa... tá claro isso? a mesma coisa, perguntando de uma forma mais ampla, sobre os filhos, por exemplo, filhos de proveta... enfim...] Se eu tenho como concepção, que ele vai ser um ser totalmente diferente daquele... do qual ele vai ser clonado, ele vai ter uma alma sua, tudo... um espírito seu... tudo próprio dele... não há... eu não imagino um outro (nome do entrevistador) sentado aqui, na minha frente, igualzinho... pode tirar, clonar você que... não vai ser uma outro (nome do entrevistador), [Ou uma outra (nome da entrevistada...)] (risos) Não vai... não vai, basta uma.

$\mathrm{Na}$ medida em que a aluna confirma, ao longo de todas as respostas, que o clone será igual biologicamente e diferente socialmente, depreende-se que, nessa representação, natureza social e natureza biológica não são interdependentes, não se determinam. Pensar dessa maneira implica também, teoricamente, acreditar que uma criança aprende a controlar os esfíncteres anais independente das condições históricas. Em outras palavras, o aprender a fazer cocô seria um controle de ordem fisiológica sem qualquer relação com a cultura. Ora, sabemos que as crianças apreendem não só a fazer e a não fazer, mas também, e ao mesmo tempo, como fazer e onde fazer, e essas determinações são 
históricas, variam de cultura para cultura. Não podemos imaginar pessoas, mesmo que geneticamente iguais como sendo biologicamente iguais, essencialmente, porque não há determinações genéticas que não sejam interdependentes das determinações sociais.

Concepções deterministas como essas representam os alicerces das teorias racistas que sustentam a existência de homens certos para lugares certos e defendem teorias que naturalizam as relações de dominação entre os homens. Para efeito de controle social, é importante para as classes dominantes que a sociedade, como um todo, adote uma concepção determinista de homem, seja ela inatista ou empirista. Adotar uma concepção determinista de indivíduo corresponde a uma naturalização do indivíduo. Naturalizá-lo implica retirar da sociedade as responsabilidades que lhe cabem na formação dos homens que a constituem. Trata-se, pois, não só de um equívoco teórico, de uma falha na compreensão da realidade, mas desvios de implicações políticas relevantes.

No marco das sociedades industriais capitalistas, o racismo, antes de ser uma ideologia para justificar a conquista de outros povos, foi muitas vezes uma forma de justificar as diferenças entre classes, principalmente nos países em que a linha divisória das classes sociais tende a coincidir com a linha divisória das raças, o que significa afirmar que ele serviu como "arma na luta de classes". (PАтто, 1993, p. 32)

Pode-se refletir sobre as formas de representação do ser humano valendo-se das teorias epistemológicas que explicam a constituição e o desenvolvimento do homem, tendo como principal referência a origem do conhecimento. A fonte das idéias, a origem do conhecimento humano decorrem da relação entre o sujeito e o objeto envolvidos no processo de conhecimento, o que necessariamente pressupõe uma representação de sujeito, o ser humano, e também uma representação de objeto de conhecimento. As teorias do conhecimento derivam-se de diferentes representações de ser humano e pretendem compreender como se dão as relações entre o sujeito cognoscente e o objeto cognoscível.

As representações de ser humano - que se baseiam no inatismo e/ou no empirismo, por conceberem o indivíduo naturalizado - têm significativos reflexos nas atitudes, nas emoções, nas reflexões dos sujeitos, pois influenciam as relações sociais, profissionais ou não, estabelecidas por esses mesmos sujeitos. Caso esses sujeitos tenham como profissão a educação, a concepção de educação desses sujeitos 
será mediada por essa representação de homem. Em suma, pode-se dizer que também naturalizam a educação, atribuindo a ela o caráter de reprodução da sociedade dividida entre os dominados e os dominantes. A educação, nesse sentido, pode ser compreendida como modeladora e/ ou reforçadora das características inatas dos indivíduos. Portanto, a sua função é de adaptar o indivíduo a seu lugar na sociedade. O sentido político da educação, visto por esse prisma, é apenas reproduzir as relações sociais como são produzidas.

A representação social de ser humano dos alunos, construída pela pesquisa empírica, engendra um conteúdo inatista de ser humano, implicando uma impossibilidade de transformação; o ser humano é, e sempre será, tal como nasceu, independente das relações com o seu meio. Associado a uma visão empirista, pois ao desconsiderar as características específicas de cada ser humano, admite-o produzido pelo meio em que vive; independente de suas peculiaridades, o indivíduo é moldado pela sociedade. A representação de ser humano é, ainda, elaborada como um ser imutável, não sendo assim passível de transformação que, associando-se às duas anteriores, produz uma representação cristalizada de ser humano, materializada historicamente.

Existe, então, uma representação de ser humano inata, empírica e imutável ao mesmo tempo. E, embora contraditórias e paradoxais, essas representações formam uma amálgama que representa o ser humano na atualidade.

\section{A NATUREZA HUMANA COMO SUPERAÇÃO DO “DADO" BIOLOGICAMENTE PARA O “CONSTRUÍDO” SOCIALMENTE}

Contradizendo a representação social de ser humano dos estudantes de Pedagogia e da sociedade em geral, a realidade da natureza humana é concretizada em um interminável processo de interação dialética entre as essências sociais e biológicas, a filogenia e a história sociocultural, e que tem sido representada reificadamente pelos homens.

Falar de uma natureza humana como um programa biológico ou social a ser cumprido é construir uma imagem idealizada do ser humano que não condiz com a realidade. A natureza humana é histórica, dinâmica e, como tal, deve incluir tanto o indivíduo como ser único quanto o ser universal que o homem é. A natureza humana deve apanhar o movimento da relação entre o indivíduo e a sociedade, sempre dissonante e incon- 
ciliável. Assim, é falsa qualquer tentativa de cristalização, de ruptura com o movimento, que é inerente a essa relação. Qualquer conceito que defina a natureza humana, tendo a idéia de um produto final, acabado, nega a dimensão histórica do homem, sendo, portanto, falso. O homem produz-se e reproduz-se em seu processo histórico.

Durante o longo processo em curso, da evolução dos seres vivos, ou seja, da filogenia, o homem destacou-se dos demais animais pela sua forma de organizar as relações entre os indivíduos. No exercício da atividade vital, o homem reproduz-se, sobrevive, trabalha. Ao realizar trabalho, assegura a sua existência biológica e acaba por perpetuar a espécie por meio da sua reprodução. Assim, o ser humano, ao se perpetuar, contribui para a perpetuação da espécie. Os animais produzem, é certo. Também apropriam-se de suas objetivações, o que fazem determinados biologicamente pela orientação contida em seus materiais genéticos, construída durante a evolução filogenética. Portanto, objetivam-se e apropriam-se de suas objetivações tanto quanto o homem.

$\mathrm{O}$ trabalho humano, encarado por esse aspecto, iguala o homem a todos os animais. Entretanto, no trabalho realizado, na produção de objetos, na transformação da natureza, o homem exterioriza-se, objetivase. As transformações apresentam-se ao homem como objetivações exteriores a ele, em cuja relação o sujeito reconhece o objeto para si. Ao reconhecê-lo, denomina, conceitua, subjetiva-o. O objeto produzido pelo animal, é certo, incorpora-se nele imediatamente, limitado pela sua própria existência individual; o homem relaciona-se com o seu produto universalmente, não apenas genericamente humano mas também universalmente genérico, significando que essa relação limita-se pela própria existência física dos objetos, do que se pode deduzir a capacidade transformadora do trabalho humano, pois o trabalho não apenas reproduz a natureza, também a transforma, transformando-se.

A produção dos recursos necessários à sobrevivência transforma a natureza, humaniza-a, e, ao transformá-la, transforma o próprio homem. O próprio ato da transformação é, para o homem, objeto de apropriação; assim, o homem, ao estabelecer o movimento de objetivação/subjetivação, gera o processo histórico.

O homem, no entanto, não é apenas ser natural, mas ser natural humano, isto é, um ser que é para si próprio e, por isso, ser genérico, que enquanto tal deve atuar e confirmar-se tanto em seu ser como em 
seu saber. Por conseguinte, nem os objetos humanos são os objetos naturais tais como se oferecem imediatamente, nem o sentido humano, tal como é imediata e objetivamente, é sensibilidade humana, objetividade humana. Nem objetiva nem subjetivamente está a natureza imediatamente presente ao ser humano de modo adequado. E como tudo o que é natural deve nascer, assim também o homem possui seu ato de nascimento: a história, que, no entanto, é para ele uma história consciente, e que, portanto, como ato de nascimento acompanhado de consciência é ato de nascimento que se supera. A história é a verdadeira história natural do homem. (MARX, 1991, p. 201; grifos no original)

A forma de vida superior do homem deve ser buscada na condição histórico-social da sua atividade, não na alma, como indicava a filosofia idealista, nem na evolução direta, baseada nos animais, como queria a visão naturalista do positivismo evolucionista. O diferencial do homem é a sua história social - "O indivíduo é o ser social" (MARX, 1991, p. 170; grifo no original).

As leis e teorias das ciências naturais não dão conta de abarcar todas as dimensões humanas, apesar de serem fundamentais para a sua compreensão. No que tange à natureza humana, pode-se retomar a lei da expressão dos genes como modelo explicativo do desenvolvimento dos seres vivos em um outro patamar: a equação genótipo $E$ ambiente = fenótipo é válida para todos os seres vivos, mas para que possa ser modelo explicativo da condição humana necessita ser ampliada a compreensão do seu segundo termo: o conceito de ambiente. No homem, o fenótipo (condições físicas, biológicas e psicológicas) é dinâmico (PENA, 1994). O ambiente humano, diferentemente do ambiente para o animal, é material e espiritual. A realidade do homem difere da realidade do animal. O animal, assim como o homem, objetiva-se, mas apenas o homem subjetiva-se. Então, deve-se ampliar o conceito de ambiente e redefinilo, incluindo-se a dimensão subjetiva.

A realidade humana é objetivação e subjetivação. Deve-se então reescrever aquela lei da seguinte forma: genótipo $E$ realidade $=$ fenótipo. A realidade humana são as condições objetivas e subjetivas, a matéria e o espírito, o concreto e o abstrato, o palpável e o simbólico. O genótipo (os genes humanos), por essa nova perspectiva, expressa-se em sua relação com a realidade humana, e, como foi visto, a realidade é também simbólica. Trata-se de uma realidade histórica, mutável. Portanto, 
os genes determinam o fenótipo do indivíduo influenciados também pela dimensão espiritual, subjetiva dos homens. É importante frisar que a expressão dos genes significa um processo que só termina com a morte do indivíduo, isto é, a qualquer modificação na realidade os genes expressam-se de uma determinada forma. Assim, qualquer tentativa de explicação que tome o ser humano como indivíduo imutável e isolado é falsa.

A característica transformadora do homem, síntese da evolução dos seres vivos, possibilita-se justamente pela capacidade de representação: a capacidade de representar sua experiência passada, por isso, de planejar a futura e escrever a sua história.

Antes de tudo, o trabalho é um processo entre o homem e a natureza, um processo em que o homem, por sua própria ação, media, regula e controla seu metabolismo com a natureza. [...] Uma aranha executa operações semelhantes às do tecelão, e a abelha envergonha mais de um arquiteto humano com a construção dos favos de suas colmeias. Mas o que distingue, de antemão, o pior arquiteto da melhor abelha é que ele construiu o favo em sua cabeça, antes de construí-lo em cera. No fim do processo de trabalho obtém-se um resultado que já no início deste existiu na imaginação do trabalhador, e portanto idealmente. (MARX, 1985, p. 149)

A capacidade de representar só se tornou possível mediante as interdependências das determinações biológicas e culturais. Os mecanismos dos movimentos de permanência e transformação da seleção natural, ao longo de toda a história da vida, produziu o sistema nervoso dos animais, e os homens têm o sistema mais complexo da escala zoológica. Tal sistema, responsável pela capacidade de percepção e reação, permite um grau de adaptação e transformação muito além de qualquer outra espécie de animal.

Conjuminantemente, o processo de complexificação do ponto de vista biológico e a organização social do homem foram capazes de produzir a divisão entre trabalho material e trabalho espiritual, pois a consciência pode imaginar algo diferente da práxis existente, o homem pode consciente e inconscientemente emancipar-se do mundo existente e construir teorias, teologias, filosofias, mesmo que elas entrem em contradição com a realidade existente; o trabalho material e o espiritual fazem parte de dimensões humanas que se separaram em decorrência do processo 
histórico natural (MARX, 1999, p. 45). Essa possibilidade de fragmentar a realidade, de percebê-la, advém da fragmentação dos objetos de produção e do próprio processo de trabalho, os quais determinam também, e necessariamente, o fracionamento do sujeito, o qual não se reconhece na sua objetivação, tomada por ele apenas como algo que lhe é externo. O sujeito passa de uma atitude ativa para uma atitude contemplativa, incapaz de refletir sobre si e sobre o que faz.

Marx (1991) identifica ontologicamente a reificação com a sociedade burguesa, o modo de produção e reprodução específico constituído histórica e culturalmente pelo homem. A alienação, a coisificação do homem e a fetichização da mercadoria produzem a atomização da realidade social, tornando-a uma realidade fragmentada. $\mathrm{O}$ alicerce da sociedade burguesa é a propriedade privada dos meios de produção, pois o modo de produção capitalista baseia-se na apropriação da exploração do trabalho.

\begin{abstract}
A propriedade privada torna-nos tão estúpidos e unilaterais que um objeto só é nosso quando o temos, quando existe para nós como capital ou quando é imediatamente possuído, comido, bebido, vestido, habitado, em resumo, utilizado por nós. Se bem que a propriedade privada concebe, por sua vez, todas essas efetivações imediatas da posse apenas como meios de subsistência, e a vida, à qual elas servem de meios, e a vida da propriedade privada, o trabalho e a capitalização. Em lugar de todos os sentidos físicos e espirituais apareceu assim a simples alienação de todos esses sentidos, o sentido do ter. O ser humano teve que ser reduzido a esta pobreza, para que pudesse dar à luz a sua riqueza interior partindo de si. (MARX, 1991, p. 171)
\end{abstract}

A reificação é potencializada pela mecanização racional do trabalho, e esta só é possível após o aparecimento do trabalhador livre aquele que pode vender a sua força de trabalho livremente como mercadoria -, e as duas últimas categorias (trabalhador livre e mercadoria) só puderam existir quando da universalização moderna da estrutura mercantil, no capitalismo. À proporção que o capitalismo produz-se e reproduz-se cada vez mais universalmente, a "estrutura reificada da consciência [figura] como categoria fundamental para toda a sociedade" (LUKÁCS, 1989, p. 114). Esse processo penetra cada vez mais na consciência humana. Para Lukács, a reificação é característica da universalização da estrutura mercantil, tanto no plano subjetivo quanto 
no objetivo, e se dá em razão da racionalização do processo do trabalho "que penetra até a 'alma' do trabalhador; e a fragmentação do objecto de produção é também necessariamente a fragmentação do seu sujeito" (LUKÁCS, 1989, p. 102-103).

Na estrutura atual da sociedade, na universalização do modo de produção capitalista, a reificação adquiriu uma potencialização extremada, ou seja, a reificação psíquica, produzida pela progressiva mecanização do processo de trabalho. O trabalho - a práxis do homem - representa a objetivação da subjetividade do homem. Na forma de produção e distribuição capitalista, "a mediação fundamental que o trabalho faria entre a natureza objetiva e subjetiva, entre o singular e o universal é rompida" (REsEnde, 1992, p. 198). O trabalho não é mais condição de reconhecimento, mas de isolamento. Assim, o homem nega a sociabilidade, a universalidade, pois já não se reconhece como parte de um todo, produzido em coletivo. O homem torna-se indivíduo isolado, não no sentido da individuação, mas no rumo do individualismo.

A negação da universalidade corresponde, portanto, à redução da particularidade, da singularidade, à mera existência em si; corresponde à negação da particularidade que, na realidade, só existe na sua relação com a universalidade. Não há ilusões: a expropriação da universalidade é a expropriação da singularidade. (RESENDE, 1992, p. 192-193)

Desse modo, a objetivação humana, corporificada nas relações sociais, é apropriada pelos homens, não como um produto do processo histórico humano, mas como uma coisa imediata, um fato da natureza, desumanizada. Trata-se do fenômeno da reificação, a forma pela qual os indivíduos "estabelecem a ilusão da verdade na aparência" (RESENDE, 1992, p. 157). A ilusão da aparência, como verdade, faz com que os homens e/ou os fenômenos humanos apresentem-se à consciência como fatos da natureza. A representação de si e do outro como coisa imutável, como coisa que permanece inalterada, ou ainda como fato da natureza, é filogenética e ontogenética. O processo de reificação corresponde a uma representação da realidade tal qual aparenta ser, e não tal qual é concretamente.

Na consciência reificada, o homem - produtor e produto - é apenas percebido como produto, e a cultura - produto e produtora - passa a ser percebida apenas como produtora do homem. Exclui-se, portanto, nesse pensamento, a idéia do homem como produtor de si mesmo, como indivíduo 
e como ser genérico. A objetividade do mundo social é apreendida como coisa externa ao homem, e não como um produto da objetivação do homem. O indivíduo pode se constituir tendo como referência as representações reificadas da realidade, as quais tomam a aparência pela essência, a parte pelo todo, e passam a perceber a realidade de modo fragmentado. Desse modo, o indivíduo introjeta valores, normas, interioriza a realidade tal qual é institucionalizada, como uma realidade cristalizada, imutável. Constitui-se objetiva e subjetivamente diante da realidade produzida, valendo-se de representações atomizadas, interiorizando-a como $a$ realidade possível, e não como uma das realidades possíveis.

A reificação é característica ontogenética e filogenética do homem, como é também inerente ao modo de produção capitalista; entretanto, essas afirmações podem, de imediato, dar a entender que a reificação humana é inexorável. É importante, porém, destacar a validade das assertivas, sem cair na falsidade da conclusão imediata. De um lado, tanto a condição sociobiológica do ser humano quanto a forma de organização social reificada são características do homem; não se permite, no entanto, inferir uma relação causal entre os fenômenos. Em outras palavras, a organização da sociedade não é de forma alguma consequiência da característica ontogenética e filogenética do ser humano. Pode-se postular que a organização da sociedade não favorece a superação da condição ontogenética e filogeneticamente construída, uma vez que sua permanência é condição para a própria permanência da organização social.

Afirmar que a reificação é inerente à condição humana significa, em parte, portar-se como Comte e Durkheim, pois o positivismo naturalista considera o modo de produção capitalista como objetivação natural do ser humano. Contudo, deve-se manter as assertivas iniciais e reforçálas: a reificação é tanto característica do modo de produção capitalista quanto condição ontogenética e filogenética do homem, cuja superação não é propiciada pelo modo de produção capitalista A reificação, portanto, não é orgânica, natural, autônoma e, menos ainda, eterna.

A conscientização do processo de reificação significa a conceituação da representação que a sociedade faz da realidade. A compreensão da representação da realidade deve dar lugar a propostas de elaboração da representação em conceito, o que significa superar a forma aparente da realidade e buscar aproximar-se de sua concreticidade. Compreender a realidade conceitualmente significa buscar a sua essência, 
em seu movimento, em todas as suas dimensões, apanhar as relações entre as suas dimensões, na tese e na antítese, naquilo que é e naquilo que não é, na particularidade e na universalidade. Entretanto, apreender a realidade completamente com esses preceitos é irreal, pois a realidade é histórica e, portanto, dinâmica. Assim, ao apreendê-la naquilo que é, imediatamente já não é, pois, ao explicar a realidade, esta incorpora a sua própria explicação e se transforma. Apesar de a tarefa ser hercúlea, é realizável e não se deve intimidar, pois é necessária a busca, a conceituação. E mais: conceituar apenas não é suficiente, é necessário buscar formas de mudanças das condições objetivas e subjetivas no intuito de desreificação da realidade. "Os filósofos se limitaram a interpretar o mundo de diferentes maneiras; o que importa é transformá-lo (MARX, 1999, p. 14)

Nesse ponto, e em um contexto de formação de professores, devemos ressaltar o que Enguita define como as condições para um mudança de circunstâncias.

A mudança das circunstâncias necessária para que mudem os homens, tal como entende Marx, apresenta duas características que se tornam, na escola, impossível uma e difícil a outra. Em primeiro lugar, não alude a nenhuma circunstância pessoal, nem às circunstâncias imediatas, mas à sociedade em geral. Em segundo lugar, há de ser obra dos próprios homens, não um presente vindo do exterior. A coincidência da mudança das circunstâncias com a atividade humana ou mudança dos próprios homens [...] só pode ser concebida e entendida racionalmente como prática revolucionária. (ENGUITA,1993, p. 101)

\section{CONCLUSÃo}

A proposta deste artigo originou-se do pressuposto de Adorno de que "qualquer debate acerca de metas educacionais carece de significado e importância frente a esta meta: que Auschwitz não se repita" (ADORNo, 1995b, p. 119). Adorno alerta que é necessário compreender e revelar os mecanismos que tornam as pessoas capazes das atrocidades cometidas na Europa Central. Esses mecanismos devem ser revelados aos seguidores das idéias fascistas para impedir a realização desses atos novamente. Auschwitz - que é uma metonímia da barbárie nazista - foi um campo de concentração construído pelo III Reich Alemão na Áustria, o 
qual, durante a Segunda Guerra Mundial, aniquilou em seus fornos uma parte significativa dos cerca de seis milhões de judeus. Auschwitz representa todo o espírito anti-semita alemão presente em leis contra os judeus, já em 1157 (Bızzo, 1994, p. 89).

Adorno (1995a), retomando a visão da barbárie como inerente ao processo civilizatório proposta por Freud (1976), afirma que opor-se à barbárie, portanto, é algo desesperador, por isso há necessidade de conscientização desse elemento desesperador para não ficar preso a uma retórica idealista. E o desespero deve dar lugar a propostas de resistência e mudança das condições objetivas e subjetivas, produtoras da barbárie na sociedade, propostas que necessariamente, para Adorno, passam pela educação e, fundamentalmente, pela educação infantil, dirigida a uma auto-reflexão crítica.

No passado, os conhecimentos da Física foram determinantes para a estruturação de uma visão de mundo cartesiana e atomizada; hoje, a Biologia busca esse patamar. Conceitos como DNA, clonagem, transgênicos, entre outros, estão na ordem do dia. O discurso hegemônico dicotômico, determinista e reducionista, anteriormente exposto, é originário das universidades, e que a sociedade em geral internaliza mediante filmes, documentários, impressos. São biólogos, médicos, geneticistas e bioquímicos que desconsideram que os fatos percebidos como dados da realidade já estão determinados pelas representações e conceitos, antes mesmo das suas elaborações teóricas, e assim orientam suas pesquisas, com base em visões reducionistas, e as divulgam com o status de verdades absolutas, obliterando a crítica. ${ }^{3}$

Segundo Marx, no terceiro manuscrito,

as ciências naturais desenvolveram uma enorme atividade e se apropriaram de um material que aumenta sem cessar. A filosofia, no entanto, permaneceu tão estranha para elas, quanto elas para a filosofia. [...] Mas quanto mais praticamente a ciência natural, através da indústria, se introduziu na vida humana, transformou-a e preparou a emancipação humana, tanto mais teve que completar diretamente a desumanização. A indústria é a relação histórica efetiva da natureza, e por isso da ciência natural, com o homem; por isso, ao concebê-la como desvelamento esotérico das forças humanas essenciais, compreende-se também a essência humana da natureza ou a essência natural do homem; com isto perde a ciência natural sua orientação abstrata, material, ou melhor, idealista, e se torna a base da ciência 
humana, do mesmo modo que já se tornou - ainda que de forma alienada - a base da vida humana efetiva, e dar uma base à vida e outra à ciência é, pois, de antemão, uma mentira." (MARX, 1991, p. 174; grifos no original)

Portanto, não se trata da construção de uma representação dicotômica de ser humano realizada por uma população carente de formação e informação - trata-se de uma visão de mundo hegemônica que se produz e reproduz-se no interior das universidades.

A reflexão sobre a matriz positivista das ciências naturais é fundamental para concretizar uma ciência natural do homem, podendo, dessa forma, mediar a reflexão acerca dos conteúdos curriculares do curso de Pedagogia. Com esse sentido, a Biologia Educacional deve ser mantida e/ou incluída em todas as grades curriculares dos cursos de Pedagogia e das licenciaturas, pois o conhecimento produzido pelas ciências naturais é fundamental para a compreensão dos processos de ensino-aprendizagem. Esses conhecimentos devem, entretanto, figurar como base teórica e não como explicações para quaisquer relações sociais, incluindo-se a educação. O conhecimento da natureza biológica do homem deve ser levado em conta nas reflexões sobre as relações sociais, porém faz-se necessário trabalhar as sínteses possíveis nas explicações que envolvam o homem. Quaisquer reflexões, análises, estudos, que envolvam a educação, devem ser realizados valendo-se de sínteses possíveis das ciências que estudam o homem, direta ou indiretamente.

A Biologia Educacional não deve, portanto, figurar nos currículos como um estudo propedêutico, introdutório de temas para a Psicologia, Sociologia, Filosofia. Ao contrário, deve-se buscar um conjunto articulado de conteúdos e objetivos capazes de contribuir para a produção de conceitos científicos, possibilitando, entre outras coisas, a superação da representação de ser humano que dicotomiza o biológico do social. Certamente disciplinas como a Psicologia, a Sociologia, a Filosofia e a História podem contribuir para as construções conceituais fundamentais para pensar a existência humana, entretanto se faz necessário também o contradiscurso no interior das ciências naturais, atribuição esta possível mediante a reflexão das relações entre a Biologia e a Educação.

Dito isso, considera-se que a desconstrução do discurso reducionista deva ser atribuição de todos os educadores. Explicitar a contradição no processo de construção e reconstrução do ser humano é tarefa de todos. 
Construir o conceito de ser humano mediante a síntese dialética dos fatores biológicos e sociais é essencial no processo de formação dos professores, e, como dito, outras áreas do conhecimento também devem pautar seus objetivos para a discussão desse tema. Portanto, sem medo de parecer que advogamos em causa própria, sustentamos a tese da existência da disciplina Biologia e Educação, de caráter obrigatório, em todos os currículos de qualquer licenciatura. Obviamente, uma disciplina sob a orientação dos pressupostos e referenciais aqui apresentados, até porque seria contraditório sustentar a manutenção da disciplina tal qual ela foi concebida.

Para tal defesa, agregamos um argumento a mais: os biólogos, como todos os outros grupos de cientistas das mais variadas ciências, não formam um bloco monolítico, pois existem, no interior das ciências naturais, intelectuais realizando pesquisas e reflexões epistemológicas, visando refletir para contrapor esse discurso hegemônico. E, salvo engano, cabe às áreas das ciências naturais das faculdades de educação a mediação dessas discussões a respeito dos métodos e das construções teóricas da Biologia essenciais à compreensão da existência humana.

\begin{abstract}
As a curricular subject, Educational Biology is no longer part of the contents in courses of Pedagogy since last Reforma Curricular (National Curriculum Reform). Nevertheless, this subject is essential for teaching formation. Nowadays, the social representation of what it is to be human (the same for the students of Pedagogy) is built on a hegemonious and crystallized view, which can be conceptualized as being inatistic, empiricist and immutable. This representation of men is not only a theoretical mistake or a miscomprehension of reality, but also an error that presents relevant political implications. This article is a reflection about the relation between Biology and Education, which can contribute to transform the social representation of men into a concept, by means of enlightenment; which can contribute with the process of understanding reality better. Also, it is a statement of defense to have Biology and Education back to the curriculum of Pedagogy and Licenciaturas Courses.
\end{abstract}

Key words: biology and education, educational biology, social representation. 


\section{NOTAS}

1. Frenologia é a teoria que estuda o caráter e as funções intelectuais humanas, baseando-se na conformação do crânio. Segundo Lewontin et al. (1986), a continuação das teorias frenológicas, nos fins do século XIX, foi base da teoria criminológica de tipos, formulada por Cesare Lombroso. "Por natureza, o criminoso tem fraca capacidade craniana, maxilares desenvolvidos e pesados, olhos salientes, crânio anormal e assimétrico [...] orelhas espetadas, freqüentemente o nariz chato ou torcido. Os criminosos são cegos às cores; [...] A permanência geral de um tipo racial inferior". (LomBroso, apud LewontiN et al., 1986, p. 71).

2. A consagração do teste de QI, "como algo que media uma capacidade imutável”, expressa a representação de ser humano como um ser imutável e foi analisada por Oliveira (1995).

3. Collares e Moysés, no livro Preconceitos no cotidiano escolar; ensino e medicalização, trabalham com crianças normais que, incorporando o discurso político-pedagógico-médico-científico, fracassam na escola. O mérito do livro é justamente fazer a crítica da biologização das questões sociais, em especial nos processos de ensino-aprendizagem.

\section{REFERÊNCIAS}

Adorno, T. W. Educação após Auschwitz. In: Adorno, T. W. Educação e emancipação. São Paulo: Paze Terra, 1995a. p.119-138.

Educação - para quê? In: ADoRno, T. W. Educação e emancipação. São Paulo: Paz e Terra, 1995b. p.139-154.

Bızzo, N. M. V. Meninos do Brasil: idéias sobre reprodução, eugenia e cidadania na escola. São Paulo, 1994. Tese de Livre-Docência - Faculdade de Educação, Universidade de São Paulo.

Chauí, M. Convite à filosofia. 5. ed. São Paulo: Ática, 1995.

Collares, C. A. L.; Moysés, M. A. A. Preconceitos no cotidiano escolar: ensino e medicalização. São Paulo: Cortez; Campinas: Unicamp, Faculdade de Educação/ Faculdade de Ciências Médicas, 1996.

Faculdade de Educação. Projeto político-pedagógico do curso de Pedagogia. Goiânia, 2003.

FReUd, S. O mal-estar na civilização. Obras completas, v. 21. Rio de Janeiro: Imago, 1976.

HoRKheIMER, M. Teoria tradicional e teoria crítica. 5. ed. São Paulo: Nova Cultural, 1991. 
JORNAL DO BRASIL. Rio de Janeiro, 19 ago. 2000, p. 12.

LAtour, B. Jamais fomos modernos: ensaio de antropologia simétrica. São Paulo: Editora 34, 1994.

Lewontin, R. C.; Rose, S.; Kamin. Genética e política. Portugal: Publicações Europa-América, 1986.

LuKÁcs, G. A reificação e a consciência do proletariado. In: LuKÁcs, G. História e consciência de classe: estudos de dialéctica marxista. Rio de Janeiro: Elfos; Porto, Portugal: Publicações Escorpião, 1989.

MARX, K. O capital: crítica da economia política. 2. ed. São Paulo: Nova Cultural, 1985, v. 1.

. Manuscritos econômico-filosóficos. 5. ed. São Paulo: Nova Cultural, 1991. 1999.

; Engels, F. A ideologia alemã (Feuerbach). 11. ed. São Paulo: Hucitec,

O POPUlar. Goiânia, 4 nov. 1997.p. 5.

Patto, M. H. S. A produção do fracasso escolar: histórias de submissão e rebeldia. São Paulo: T.A. Queiroz, 1993.

Pena, S. D. J. Conflitos paradigmáticos e a ética do Projeto Genoma Humano. Revista USP, São Paulo (24): 68-73, 1994.

Rego, T. C. R. A origem da singularidade do ser humano. Análise das hipóteses de educadores à luz da perspectiva de Vygotski. São Paulo, 1994. Dissertação (Mestrado em Educação) - Faculdade de Educação, Universidade de São Paulo.

Resende, A. C. A. Fetichismo e subjetividade. São Paulo, 1992. Tese (Doutorado) - Pontifícia Universidade Católica.

SouzA, A. B. C. de. O social e o biológico na constituição do ser humano: o concreto e sua representação. Goiânia, 2000. Dissertação (Mestrado em Educação) - Faculdade de Educação, Universidade Federal de Goiás.

Universidade Federal de Goiás. Resolução n. 207, de 27 de janeiro de 1984. Fixa o Currículo do Curso de Pedagogia da Universidade Federal de Goiás e dá outras providências. Conselho Coordenador de Ensino e Pesquisa, Goiânia: UFG, 1984. Anexo II. 